\title{
Dexamethasone suppresses the differentiation of stem Leydig cells in rats in vitro
}

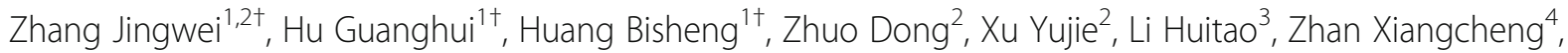
Ge Ren-Shan ${ }^{3 *}$ and Xu Yunfei ${ }^{1 *}$

\begin{abstract}
Background: It is an established fact that excess of glucocorticoids could cause the harmful effects, such as suppression on the male reproduction. Although glucocorticoids pharmacologically inhibit the Leydig cell function, their roles in Leydig cell development are unclear. Therefore, the present study was designed to investigate effects of synthetic glucocorticoid dexamethasone (DEX) on rat stem Leydig cell proliferation and differentiation.

Methods: Male Sprague-Dawley rats received a single intraperitoneal injection of $75 \mathrm{mg} / \mathrm{kg}$ EDS to eliminate Leydig cells and an in vitro culture system of the seminiferous tubules was established from Leydig cell-depleted testis. Using basal medium and Leydig cell differentiation-inducing medium (LIM) in the culture system, we examined the effects of DEX (0-100 nM) on the proliferation and differentiation of the stem Leydig cells in vitro, respectively.

Results: Results showed that LIM is a good agent to induce stem Leydig cell differentiation into Leydig cells that produce testosterone in vitro. DEX inhibited the differentiation of stem Leydig cells by reducing the expression levels of Cyp17a1 and Scarb1 and that NR3C1 antagonist RU38486 reversed the DEX-mediated effects. However, DEX are not involved with the proliferation of stem Leydig cells.

Conclusions: DEX suppressed the differentiation of rat Leydig cells in vitro and glucocorticoid-induced effects acted through NR3C1. This suppression partially targets on Cyp17a1 and Scarb1 gene expression.
\end{abstract}

Keywords: Glucocorticoid, Dexamethasone, Stem Leydig cells, Proliferation, Differentiation, Testosterone

\section{Background}

Glucocorticoids play roles in many physiological functions [1]. Through binding to the glucocorticoid receptor (NR3C1, encoded by $N r 3 c 1$ ), glucocorticoids function in the level of cells. NR3C1 is known to be a member of the nuclear steroid receptor superfamily and a ligand-dependent transcription factor that acts as a regulator in the expressions of glucocorticoid-responsive genes [2]. Endogenous glucocorticoids are cortisol (the

\footnotetext{
* Correspondence: r_ge@yahoo.com; xuyunfeibb@sina.com

${ }^{\dagger}$ Jingwei Zhang, Guanghui Hu and Bisheng Huang contributed equally to this work.

${ }^{3}$ Center of Scientific Research, the Second Affiliated Hospital and Yuying Children's Hospital of Wenzhou Medical University, Wenzhou, Zhejiang, China

'Department of Urology, Shanghai Tenth People's Hospital, Tongji University, Shanghai, China

Full list of author information is available at the end of the article
}

predominant glucocorticoid in the human) or corticosterone (the main glucocorticoid in the rat). Glucocorticoids can pharmacologically inhibit many physiological functions such as the suppression of immune system, brain, and reproduction [1,3]. Clinically, the potent synthetic glucocorticoids such as dexamethasone (DEX) are widely used as the drugs to treat symptoms of inflammation and immune disorders such as systemic lupus erythematosus. However, the long-term use of DEX could cause many side effects.

Indeed, glucocorticoids can suppress the male reproduction [1]. One of the targets by glucocorticoids is the Leydig cell in the testis. Leydig cells are the main cells to secrete testosterone, which is necessary for the onset of male puberty and spermatogenesis and the maintenance of the secondary sexual characteristics [4]. Leydig cells contain NR3C1 and glucocorticoids suppress

(c) The Author(s). 2019 Open Access This article is distributed under the terms of the Creative Commons Attribution 4.0 International License (http://creativecommons.org/licenses/by/4.0/), which permits unrestricted use, distribution, and reproduction in any medium, provided you give appropriate credit to the original author(s) and the source, provide a link to the Creative Commons license, and indicate if changes were made. The Creative Commons Public Domain Dedication waiver (http://creativecommons.org/publicdomain/zero/1.0/) applies to the data made available in this article, unless otherwise stated. 
testosterone biosynthesis mediated by NR3C1 [5-7]. However, the effects of glucocorticoids on the pubertal development of Leydig cells are unclear. Clinically, it has been demonstrated that the children with the treatment of $>400 \mathrm{mg} / \mathrm{kg}$ cumulative dose of corticosteroids in systemic lupus erythematosus had a delay of puberty [8].

In the present study, a Sprague-Dawley rat Leydig cell development was used to address the effects of DEX on Leydig cell development. The pubertal development of rat Leydig cells in vivo can be conceptually divided into four stages: stem, progenitor, immature, and adult Leydig cells [4]. This development of Leydig cells can be mimicked in vitro by the induction of stem Leydig cells into the Leydig cell lineage on the surface of the seminiferous tubules after 21 days of culture in the presence of Insulin-Transferrin-Selenite (ITS), luteinizing hormone $(\mathrm{LH})$ and lithium (LI) together $[9,10]$. In this model, Leydig cells were eliminated by a drug called ethane dimethane sulfonate (EDS) and the Leydig cell-free tubules were cultured $[9,10]$. The stem Leydig cells were located on the surface of the seminiferous tubules and they can either enter the proliferative status or commit to the Leydig cells in the presence of different growth factors [11]. Stem Leydig cells can commit to the Leydig cell lineage by expressing androgen-biosynthetic enzymes, including CYP11A1 (encoded by Cyp11a1), HSD3B1 (encoded by Hsd3b1), CYP17A1 (encoded by Cyp17a1), and HSD17B3 (encoded by Hsd17b3), SRD5A1 (encoded by Srd5a1). In addition, LHCGR (encoded by Lhcgr), SCARB1 (encoded by Scarb1) and StAR (encoded by Star) also play essential roles in Leydig cell development. In the present study, we examined the effects of DEX on the proliferation and differentiation of the stem Leydig cells in vitro.

\section{Methods \\ Chemicals}

DEX and RU38486 (NR3C1 antagonist) were purchased from Sigma-Aldrich (MO, USA). EDS was purchased from Pterosaur Biotech Co. (Zhejiang, China).

\section{Animals}

Male Sprague-Dawley rats were purchased from Shanghai Laboratory Animal Co. Ltd. (Shanghai, China). Rats were adjusted in a $12 \mathrm{~h}$ dark/light cycle at $23 \pm 2{ }^{\circ} \mathrm{C}$ and 45 to $55 \%$ relative humidity for a week, given ad libitum accesse to water and food. At the time of experiment, the median weight of rats was $523 \mathrm{~g}(399 \mathrm{~g} \sim 607$ g) and the median age of rats was 91 days (86 days $\sim 95$ days). EDS was dissolved in dimethyl sulfoxide and sterile water $(1,3, \mathrm{v} / \mathrm{v})$ and these rats received a single intraperitoneal injection of $75 \mathrm{mg} / \mathrm{kg}$ EDS to eliminate Leydig cells according to the previous study [12]. All animal procedures were approved by the Institutional Animal Care and Use Committee of Tongji University and were performed in accordance with the National Research Council (US) Committee Guide for the Care and Use of Laboratory Animals.

\section{Seminiferous tubule isolation and culture}

After EDS treatment, rats were housed for additional 7 days to deplete all Leydig cells [13]. At this time, the rats were killed by asphyxiation with $\mathrm{CO}_{2}$ of progressively increasing concentration ( $100 \%$ eventually) and underwent bilateral orchidectomy via a $2-$ to $3-\mathrm{cm}$ abdominal incision, then testes were collected immediately and decapsulated. Seminiferous tubules were mechanically separated from the interstitium. Tubule fragments of equal total length (about $3 \mathrm{~cm}$ ) were placed randomly in each well of 12-well plates. Basal medium (BM) was used for culturing the seminiferous tubules at $34{ }^{\circ} \mathrm{C}$ and $5 \% \mathrm{CO}_{2}$, which was a mixture of DMEM/F-12 plus an equal volume of Medium 199 ( $\mathrm{pH} 7.2$ ), sodium bicarbonate $(2.2 \mathrm{mg} / \mathrm{mL})$, bovine serum albumin $(1 \mathrm{mg} / \mathrm{mL})$, and penicillin/streptomycin $(100 \mathrm{U} / \mathrm{mL}$ and $100 \mu \mathrm{g} / \mathrm{mL})$, respectively. For proliferation investigation of stem Leydig cells, seminiferous tubules were cultured without or with DEX (1, 10, and $100 \mathrm{nM})$. The concentrations of DEX were selected based on its inhibition on steroidogenesis in rat progenitor Leydig cells [14].

Leydig cell medium was selected based on the treatment of BM in presence of $5 \mathrm{mM}$ ITS, $5 \mathrm{ng} / \mathrm{ml} \mathrm{LH}, 5$ $\mathrm{mM}$ LI, or ITS + LH + LI $[9,15]$. The Leydig cell differentiation-inducing medium (LIM) was constructed by containing $5 \mathrm{mM}$ ITS, $5 \mathrm{ng} / \mathrm{ml} \mathrm{LH}$, and $5 \mathrm{mM}$ LI. The seminiferous tubules in LIM were cultured for 21 days on which stem Leydig cells fully differentiate into the Leydig cell lineage $[9,15]$. To investigate the effects, we added DEX and/or RU38486 (a NR3C1 blocker) of different concentrations to this LIM on the basis of the previous studies $[5,16]$.

Media were collected and frozen $\left(-20^{\circ} \mathrm{C}\right)$ for testosterone assay. Tubules were immediately fixed for morphological study, total RNA extraction, and total protein extraction. Duplicated wells were used at each time point, and each experiment was replicated at least three times.

\section{Medium testosterone analysis}

The IMMULITE 2000 Immunoassay System and Total Testosterone Kit from Siemens Healthcare Diagnostics Products Limited (Gwynedd, UK) was used to detect medium testosterone concentrations, according to the manufacturer's instructions. The immunochemiluminometric assay was able to detect as low as $0.2 \mathrm{ng} / \mathrm{ml}$ testosterone with 5.75 and $7.53 \%$ of intra- and inter-assay CVs. 


\section{$3 \beta$-Hydroxysteroid dehydrogenase enzymatic staining to label Leydig cells}

After the culture in BM or LIM for 21 days, seminiferous tubules tubules were air-dried and stained to evaluate HSD3B1 activity of Leydig cells as previously described [17]. At a minimum, air-dried tubules were incubated with $0.4 \mathrm{mM}$ etiocholanolone as the steroid substrate and $\mathrm{NAD}^{+}$as a cofactor for $30 \mathrm{~min}$. A staining solution without $0.4 \mathrm{mM}$ etiocholanolone was used for nonspecific staining. Then, tubules were washed with PBS and fixed using $4 \%$ paraformaldehyde for $30 \mathrm{~min}$ at room temperature. The tubules were visualized in a microscope.

\section{EDU incorporation into stem Leydig cells}

Stem Leydig cells reside on the surface and their proliferation was measured by the Click-iT ${ }^{\circ}$ EDU (EDU) Alexa Fluor 488 Imaging Kit (Life Technologies, OR, USA) following the manufacturer's instructions and the EDU incorporation into cells was performed as previously described [11]. In our previous study, we demonstrated that EDU-positive cells are located outside myoid cells [11]. Briefly, the seminiferous tubules were isolated and cultured in the BM without or with DEX for the additional 5 days. Following this culture, tubules were incubated in $2 \mathrm{ml}$ of 1:1000 diluted EDU for $24 \mathrm{~h}$ and then were washed twice with PBS buffer containing $3 \%$ bovine serum albumin. Tubules were subsequently fixed in $4 \%$ paraformaldehyde for $30 \mathrm{~min}$ at room temperature and washed twice. Then, tubules were incubated with reaction solution for $45 \mathrm{~min}$ and washed again, protected against exposure to light. Finally, tubules mounted on a slide were visualized using a fluorescence microscope (Olympus, Tokyo, Japan). By the aid of Image Pro Plus 6.0 software (Media Cybernetics, Inc., MD, USA), EDU-positive cells were calculated by the total surface area of the seminiferous tubules.

\section{Cell immunofluorescence}

Seminiferous tubules cultured in the LIM for 21 days were embedded in $2 \%$ argose gel and cross sections $(10 \mu \mathrm{m})$ were cut. The sections were fixed in $4 \%$ paraformaldehyde for $30 \mathrm{~min}$ at room temperature and washed with $\mathrm{Ca}^{2+}$ and $\mathrm{Mg}^{2+}$ free HBSS (0.5\% BSA). Then sections were incubated with mouse monoclonal antibody against $\alpha$-smooth muscle actin ( $\alpha$-SMA, Abcam, ab7817, 1:200) and rabbit monoclonal antibody against CYP17A1 (Abcam, ab125022, 1:200) for $60 \mathrm{~min}$. Following the primary antibody incubation, sections were incubated with conjugated secondary antibody (Donkey anti-Mouse IgG $(\mathrm{H}+\mathrm{L})$ Highly Cross-Adsorbed Secondary Antibody, Alexa Fluor ${ }^{\circ}$ 594, Invitrogen, A-21203, 1:500) \& (Donkey Anti-Rabbit IgG $(\mathrm{H}+\mathrm{L})$ Dylight 488, Bioworld, BS10018, 1:100) for $30 \mathrm{~min}$.
Peritubular myoid cells were labeled by $\alpha$-SMA and Leydig cells were labeled by CYP17A1. DAPI (Abcam Trading Shanghai Company, Shanghai, China) was used as a counterstain. The sections were visualized under a fluorescence microscope (Olympus, Tokyo, Japan) and CYP17A1-positive cells were counted and calculated. We counted five cross sections and averaged them for each experiment.

\section{Leydig cell isolation}

A complete description of the cell isolation procedure in the Leydig cell lineage has been described [18]. The stem Leydig cells were isolated according to immunoselection method by positively selecting platelet-derived growth factor receptor $\alpha$ (PDGFRA) positive cells and negatively selecting LHCGR-negative cells from forty 6-day-old male rat testis [19]. The purity of stem Leydig cells was about 99\% after immunofluroscent staining of PDGFRA using anti-PDGFRA antibody. Progenitor Leydig cells were purified from forty 21-day-old rat testes [18]. Testes were decapsulated and dispersed in medium 199 plus $0.25 \mathrm{mg} / \mathrm{ml}$ collagenase (Boehringer Mannheim Biochemicals, Indianapolis, IN) by a shaking $34^{\circ} \mathrm{C}$ water bath $(75 \mathrm{rpm})$ for $10 \mathrm{~min}$. The separated cells were harvested and filtered through two layers of nylon mesh $(100 \mu \mathrm{m})$. Then the cells were centrifuged at $250 \times \mathrm{g}$ and resuspended in 55\% isotonic Percoll. Density gradient centrifugation was subsequently conducted at $25000 \times \mathrm{g}$ for $45 \mathrm{~min}$ at $4{ }^{\circ} \mathrm{C}$, and the progenitor Leydig cell fraction was collected between densities of 1.064 and 1.070 $\mathrm{g} / \mathrm{ml}$. After washing with HBSS, the cells were centrifuged at $250 \times \mathrm{g}$ and resuspended in phenol red-free medium (DMEM-Ham's F-12, Sigma, St. Louis, MO) containing $1 \mathrm{mg} / \mathrm{ml} \mathrm{BSA}$. Immature Leydig cells were isolated from eighteen 35-day-old rat testes [18]. Testes were perfused with $1 \mathrm{mg} / \mathrm{ml}$ collagenase in medium 199 via the testicular artery before decapsulation [18]. Other procedure was similar to progenitor Leydig cell isolation. The immature Leydig cell fraction was collected from the Percoll gradient between densities of 1.07 and $1.088 \mathrm{~g} /$ $\mathrm{ml}$. Adult Leydig cells were purified from six 90-day-old rat testes according to the method of Klinefelter et al. [20]. Before the Percoll density gradient centrifugation, collagenase dispersed interstitial cells were elutriated in the Beckman JE-6B elutriation chamber (Palo Alto, CA) at a flow rate of $16 \mathrm{ml} / \mathrm{min}$ at $2000 \mathrm{rpm}$, after which adult Leydig cells were collected from the Percoll gradient between densities of 1.07 and $1.09 \mathrm{~g} / \mathrm{ml}$. Purities of Leydig cell fractions for progenitor, immature and adult Leydig cells were determined by HSD3B1 staining as previously described [21]. The purities of progenitor, immature, and adult Leydig cells were more than 95\%. Four isolations were performed for each cell types. The Leydig cells of all cell types were collected for RNA extraction. 
Real-time quantitative polymerase chain reaction (qPCR) Total RNAs were extracted from cells in the Leydig cell lineage and the seminiferous tubules cultured in the LIM for 21 days using Trizol $^{\circ}$ Reagent (Life Technologies, CA, USA) according to the manufacturer's instruction. The Leydig cell genes and corresponding primers with at least one span intron were used as described previously [22-25], including Nr3c1, Lhcgr, Scarb1, Star, Cyp11a1, Hsd3b1, Cyp17a1, Hsd17b3, Srd5a1. Rps16 was used as an internal control gene for the relative mRNA levels. Reactions were performed and the cDNA was synthesized using Reverse Transcription System (Promega, WI, USA). The qPCR was performed in a $25-\mu \mathrm{l}$ reaction volume using SYBR Green detection system (Bio-Rad Laboratories, Inc., CA) and Light Cycler 480 SYBR Green I Master (Roche Diagnostics, IN, USA). Reactions were run for up to 40 cycles and the melting curves were routinely checked afterward. The data were analyzed using the $\mathrm{Ct}$ value and the standard curve method as previously described [26].

\section{Western blotting}

Seminiferous tubules were cultured in the LIM for 21 days and radioimmuno-precipitation assay buffer (Beyotime Biotechnology, Shanghai, China) was used to isolate total proteins. An Enhanced BCA Protein Assay Kit (Beyotime Biotechnology, Shanghai, China) was used to determine the protein concentrations. $50 \mu \mathrm{g}$ of proteins were loaded onto $10 \%$ polyacrylamide gels containing sodium dodecyl sulfate and transferred onto the nitrocellulose membranes. The membranes were blocked with $5 \%$ non-fat milk for $2 \mathrm{~h}$ and were incubated overnight at $4{ }^{\circ} \mathrm{C}$ with primary antibodies: anti-SCARB1 (MultiSciences, 70-ab1967-050, 1:1500), anti-CYP17A1 (MultiSciences, 70-ab1766-050, 1:1000), and anti- $\beta$ actin (ACTB, Cell Signaling Technology, 4970, 1:1000). After washing, the membranes were incubated with HRP-conjugated anti-rabbit IgG secondary antibody (MultiSciences, 70-GAR0072, 1:2000) for $2 \mathrm{~h}$ at room temperature and washed again. Membranes were processed with Western Bright ${ }^{\circ}$ ECL (Advansta, CA, USA) and the intensity of immunoreactive bands were analyzed with Image Lab software 3.0 (Bio-Rad Laboratories, Inc., CA).

\section{Statistical analysis}

Values are expressed as mean $\pm \mathrm{SEM}$, and data were analyzed by the GraphPad Prism 6 (GraphPad Software Inc., CA). Multiple groups were performed by one-way ANOVA followed by ad hoc Tukey's comparison of all columns compared with the control column. Before ANOVA was used for statistical analysis, the normal distribution and variance homogeneity were confirmed. Mean value comparisons between 2 groups were performed by student $t$ test. Before student $t$ test was used for statistical analysis, the normal distribution is confirmed. Differences were considered significant at $P<0.05$.

\section{Results \\ LIM can induce stem Leydig cell into the Leydig cell lineage}

To investigate the condition of in vitro differentiation of stem Leydig cells into the Leydig cell lineage, we cultured the seminiferous tubules in BM (control), or BM containing the following agents: ITS, LH, LI, or ITS + $\mathrm{LH}+\mathrm{LI}$. As shown in Fig. 1a-b, only ITS $+\mathrm{LH}+\mathrm{LI}$ robustly induced testosterone production during week 2-3. Compared to the BM (Fig. 1c), which had no Leydig cells formed on the surface of the seminiferous tubules, ITS + LH + LI-treated tubules had Leydig cells with $18 \pm 1$ Leydig cells $/ 1000 \mu \mathrm{m}^{2}$ (Fig. 1d). This indicates that LIM is a good agent to induce stem Leydig cell differentiation into Leydig cells that produce testosterone in vitro.

\section{DEX blocks stem Leydig cell differentiation}

To induce the stem Leydig cells to differentiate into Leydig cells, the seminiferous tubules were cultured in LIM for consecutive 21 days, thus producing testosterone as above. When the seminiferous tubules were cultured for 21 days in LIM plus various concentrations of DEX, DEX concentration-dependently decreased medium testosterone levels (Fig. 2a). This signifies that DEX blocks Leydig cell development/steroidogenesis. Then, we further examined whether the effects of DEX were antagonized by RU38486, a NR3C1 antagonist. Indeed, RU38486 $1 \mu \mathrm{M}$ alone did not affect the Leydig cell development/steroidogenesis, but it reversed DEXinduced testosterone suppression (Fig. 2b). This indicates that DEX blocks the Leydig cell development/ steroidogenesis via the NR3C1. We stained the Leydig cells after 21-day culture in LIM by CYP17A1, the biomarker of Leydig cells. Leydig cells appeared on the surface of seminiferous tubule (11 \pm 3 Leydig cells/tubule in the cross section, Fig. 3a). When cultured with $10 \mathrm{nM}$ DEX, CYP17A-positive Leydig cell number formed was remarkably reduced (Fig. 3b). When $100 \mathrm{nM}$ DEX was used, almost no Leydig cells were formed (Fig. 3c). When $100 \mathrm{nM}$ DEX and RU38486 $1 \mu \mathrm{M}$ in combination were used, DEX-mediated suppression of the formation of CYP17A1-positive Leydig cells were reversed (Fig. 3d), although RU38486 alone did not affect the formation of Leydig cells (Fig. 3e). The quantitative data was listed on Fig. 3f. This further confirmed that DEX inhibited the formation of CYP17A1-positive Leydig cells and that RU38486 reversed the DEX-mediated effects. 
A

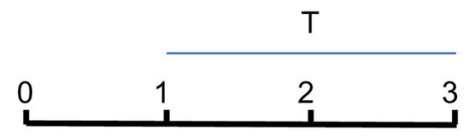

Seminiferous tubule culture (week)
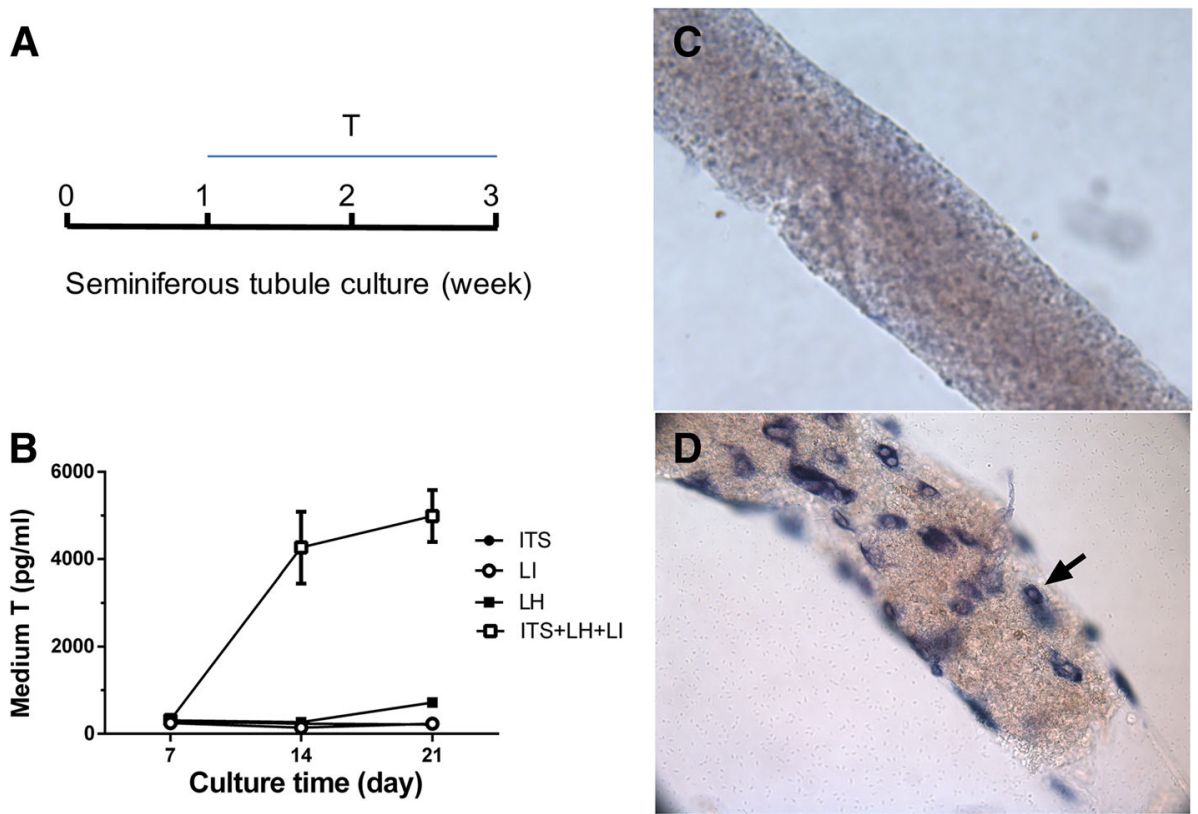

Fig. 1 An in vitro culture system for differentiating stem Leydig cells on the surface of seminiferous tubule into Leydig cell lineage. Panel $\mathbf{a}-\mathbf{b}$ : The testosterone production by seminiferous tubules in the BM contained ITS $5 \mathrm{mM}, \mathrm{LH} 5 \mathrm{ng} / \mathrm{ml}, \mathrm{LI} 5 \mathrm{mM}$, or ITS $5 \mathrm{mM}+\mathrm{LH} 5 \mathrm{ng} / \mathrm{ml}$ + LI $5 \mathrm{mM}$ (the LIM). Mean \pm SEM, $n=4-8$. Panel c-d: Seminiferous tubules were stained with HSD3B1 and Leydig cells were indicated by black arrows. Panel: (c) Seminiferous tubule after 21 days of culture in the BM (no Leydig cells were observed); (d) Leydig cells were observed with HSD3B1 staining (cells indicated by black arrow on the surface of a seminiferous tubule) after 21 days of culture in the LIM

\section{DEX down-regulates Leydig cell-specific genes and} protein expressions

In the previous study, we used regular PCR and found that $N r 3 c 1$ was detected in progenitor, immature, and adult Leydig cells [5]. In the present study, we also included stem Leydig cells and used qPCR to measure $N r 3 c 1$ levels and we found that $N r 3 c 1$ was present in all Leydig cell lineage cells (since the negative control showed no signal, data not shown), including stem Leydig cells, further supporting that stem Leydig cells are the target of DEX. We examined the effects of DEX on the expression levels of Leydig cell-specific genes (Fig. 4). Statistically, we found 10 and $100 \mathrm{nM}$ DEX significantly down-regulated the mRNA levels of the steroidogenic enzyme gene Cyp17a1 (encoding CYP17A1) and scavenger receptor class B member 1 gene Scarb1 (encoding SCARB1). However, DEX did not affect other 6 mRNA levels. In parallel, DEX also down-regulated CYP17A1 and SCARB1 protein levels (Fig. 5). RU38486 reversed DEX-mediated effects. These results indicate that DEX inhibits the differentiation of Leydig cells by partially reducing the expression levels of Cyp17a1 and Scarb1.
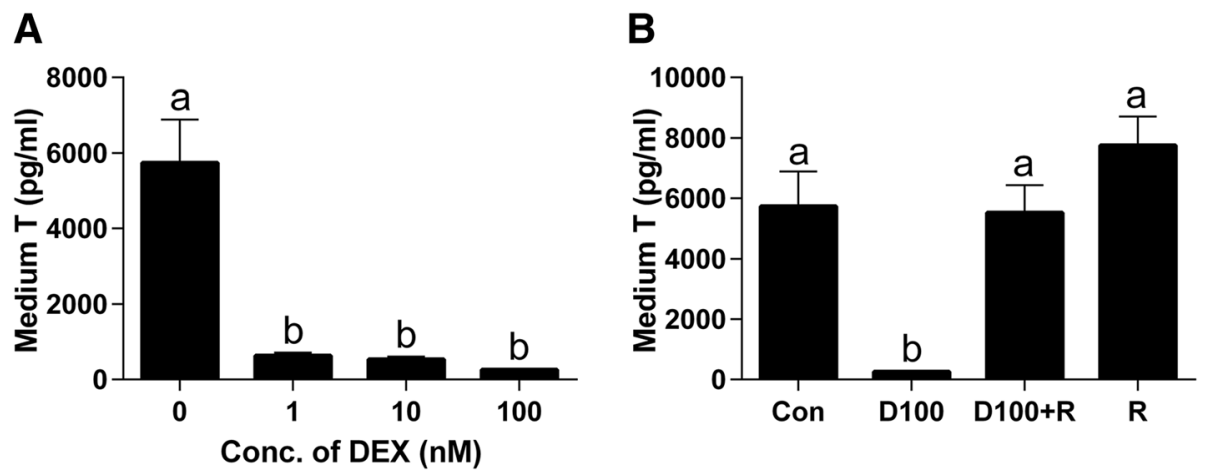

Fig. 2 Effects of DEX on the differentiation of stem Leydig cells. Seminiferous tubules were cultured in the LIM in the presence of DEX alone or with RU38486 or RU38486 alone for 21 days, medium testosterone (T) levels were measured ( $n=4-8)$. Panel: (a) DEX (0-100 nM); (b) DEX alone or with RU38486 or RU38486 alone. D100 = DEX $100 \mathrm{nM}$ and R=RU38486 $1 \mu \mathrm{M}$. The data were presented as the mean \pm SEM. Identical letters showed no significant difference between two groups at $P<0.05$ 

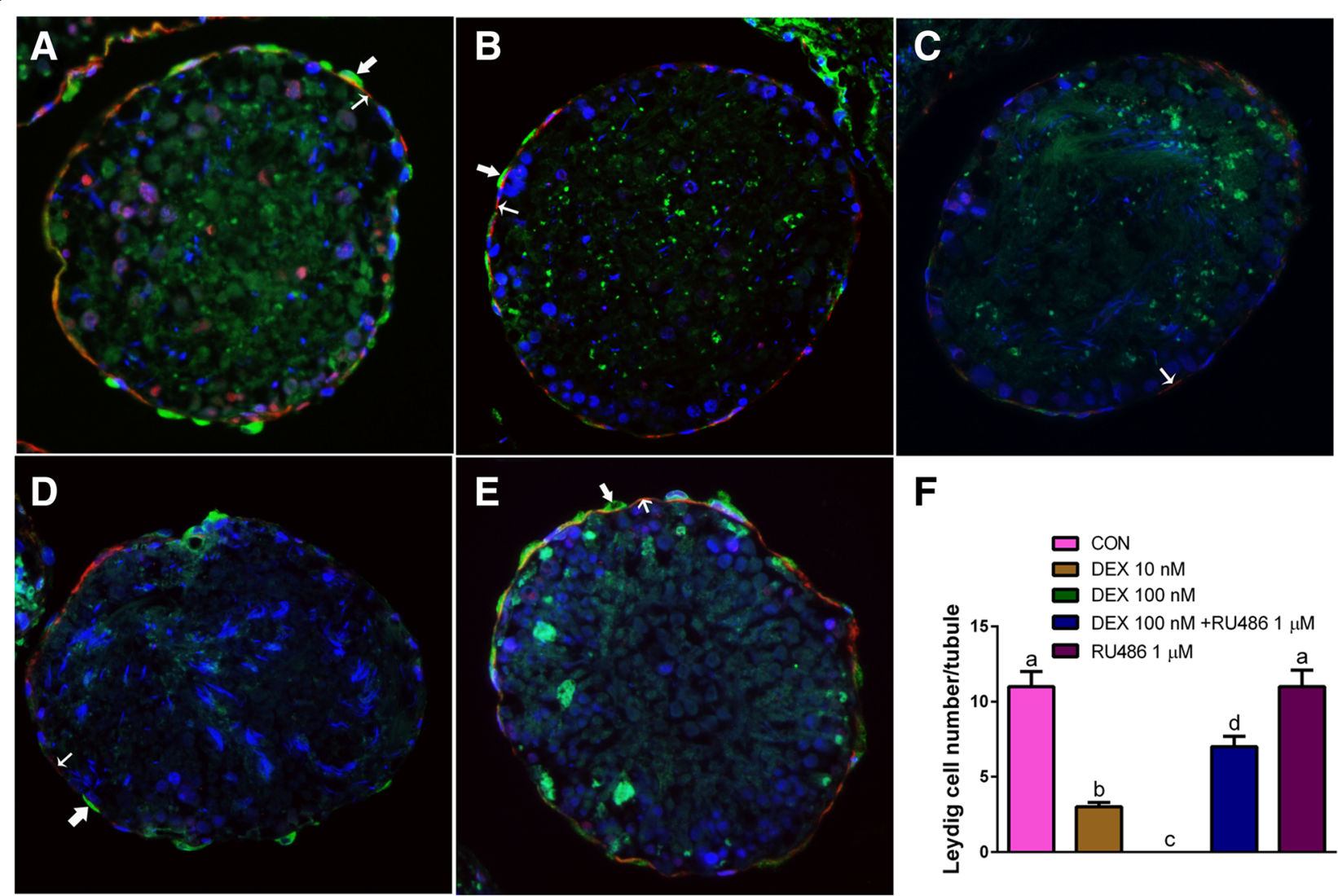

$\mathbf{F}$

Fig. 3 DEX reduces the formation of Leydig cells. Panel a-f: Immunofluorescent staining of tubule section after DEX alone or with RU38486 or RU38486 alone treatment in the LIM for 21 days. Cross sections with CYP17A1 staining (green color, bold arrow) showed the formation of Leydig cells. a-Smooth muscle actin staining (red color, light arrow) showed the myoid cells, which surround the seminiferous tubules. CYP17A1 positive cells were outside the a-smooth muscle actin positive cells, indicating that they were differentiated from the stem Leydig cells on the surface of

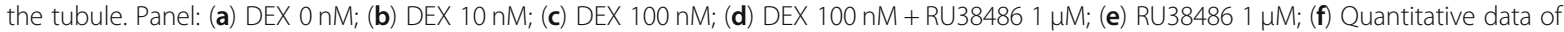
Leydig cell number per cross section $(n=3)$. The data were presented as the mean \pm SEM. Identical letters showed no significant difference between two groups at $P<0.05$

\section{DEX does not influence stem Leydig cell proliferation}

To explore the probalble effects of DEX on the proliferation of stem Leydig cells, we used an in vitro seminiferous tubule culture system. In this system, isolated seminiferous tubules were cultured for 5 days without or with 1-100 nM DEX in the BM. Then, EDU incorporation into stem Leydig cells on the surface of seminiferous tubules were observed and EDU-positive cells were located outside myoid cells [15]. As shown in Fig. 6a-c, in the BM, the EDU incorporative rate into the stem Leydig cells was $1.11 \pm 0.21$ cells $/ \mathrm{mm}^{2}$ and DEX treatment did not affect the EDU incorporation rate into stem Leydig cells. This suggests that DEX are not involved with the proliferation of stem Leydig cells.

In order to further investigate whether DEX can affect stem Leydig cells pool, we cultured the seminiferous tubules in the BM without or with various concentrations of DEX (1-100 nM) for 7 days. To induce these stem Leydig cells into the Leydig cells, the tubules were transferred to the LIM for extra 14 days. Testosterone levels in the medium were not significantly affected when compared to control (Fig. 6d), confirming that DEX did not increase stem Leydig cell number.

\section{Discussion}

Endogenous glucocorticoid, cortisol or corticosterone, are required for the development in fetal tissues and organs. However, both acute and chronic stress experiments have shown that high glucocorticoids inhibited testosterone secretion [27]. This effect is due specifically to the increased circulating glucocorticoid levels in the blood and action via NR3C1 because ACTH treatment in adrenalectomized animals fails to replicate these findings [28]. In this study, we found that glucocorticoids also targeted stem Leydig cells to inhibit their differentiation.

In the present study, we demonstrated that stem Leydig cells on the surface of the Leydig cell-depleted seminiferous tubules in the medium containing ITS, LH, and LI could be induced into testosterone-producing 


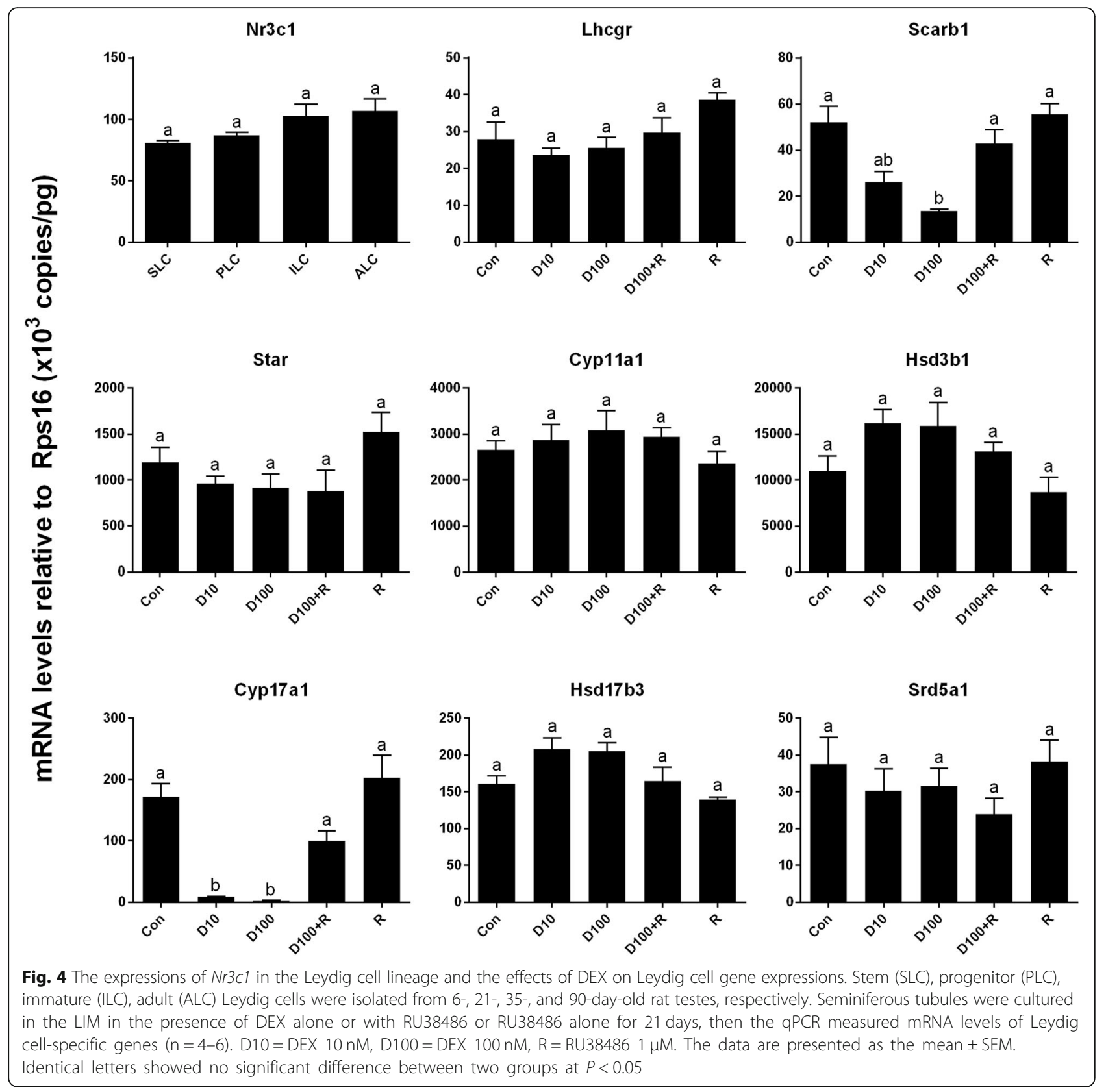

Leydig cells in vitro. This system is very useful for testing the chemicals like DEX to regulate stem Leydig cell differentiation and proliferation without the interference of hypothalamus-pituitary secreted hormones as described [11]. In the present study, we found that NR3C1 was expressed in stem, progenitor, immature, and adult Leydig cells (Fig. 4). Our previous study also demonstrated that although the expression levels of $N r 3 c 1$ were not changed, the binding sites of NR3C1 were significantly increased during later stage of development from immature to adult Leydig cells [29]. In this system, we found that DEX suppressed the differentiation of stem Leydig cells in vitro and glucocorticoid-induced effects acted through NR3C1.

The present study demonstrated that DEX suppressed the differentiation of stem Leydig cells in vitro and glucocorticoid-induced effects acted through downregulating the expression levels of Cyp17a1 and Scarb1. The down-regulation of these two proteins could cause the reduction of testosterone synthesis. Apparently, DEX acts via binding to NR3C1, since RU38486, a NR3C1 antagonist, reversed DEX-mediated suppression of Cyp17a1 and Scarb1 expressions (Fig. 4) and testosterone levels (Fig. 2). Lower level of Cyp17a1 and its protein after DEX treatment were due to the absence of 


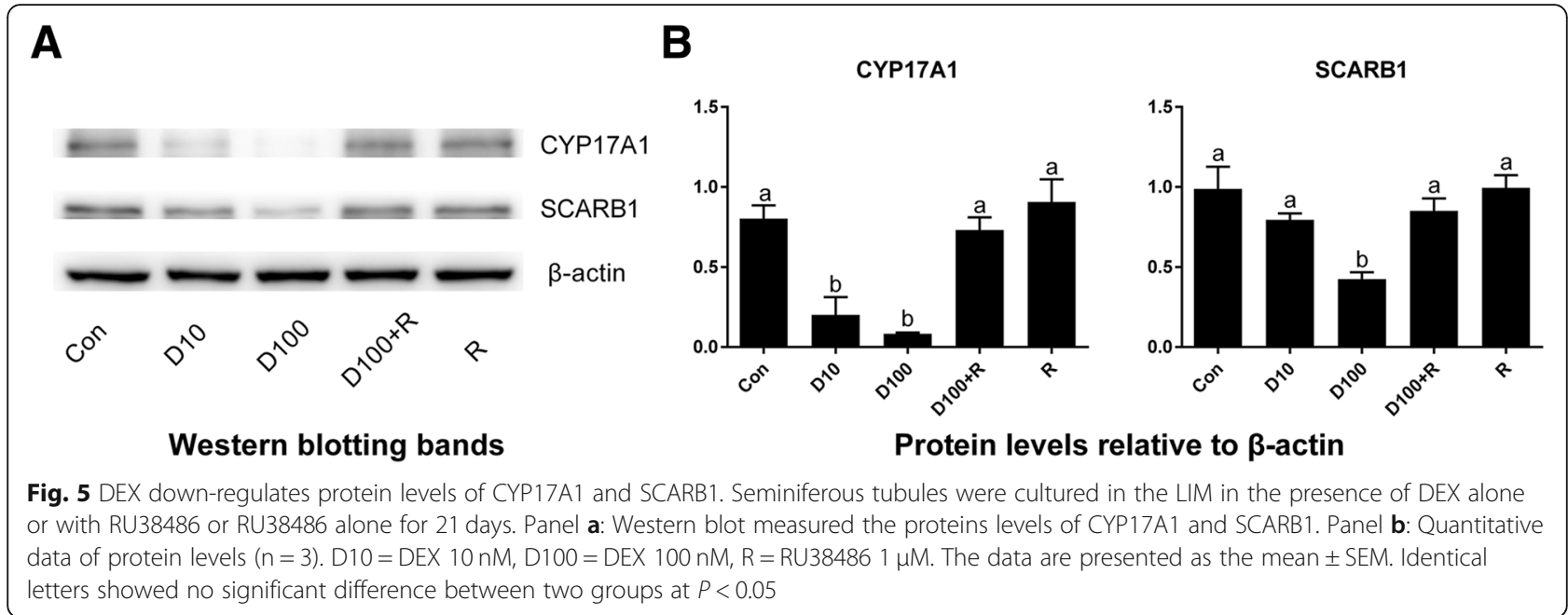

CYP17A1-positive Leydig cells (Fig. 3). CYP17A1 is among the first three important steroidogenic enzyme genes during the initial development of stem into progenitor Leydig cells [30]. Although the exact mechanism of DEX to down-regulate Cyp17a1 in the Leydig cell lineage is not clear, research using adult-derived bovine steroidogenic cells has shown the competition between COUP-TFII and NR5A1 for binding to an overlapping response element in the promoter region of gene encoding Cyp17a1 to inhibit NR5A1-induced Cyp17a1 expression [31]. NR5A1 is a critical ligand-free nuclear receptor transcription factor for promoting Leydig cell development. NR5A1 can bind to the promoters of many Leydig cell genes including Cyp17a1 [32]. Null mutation of NR5A1 caused Leydig cell agenesis [33]. Forced expression of NR5A1 can even convert stem cells

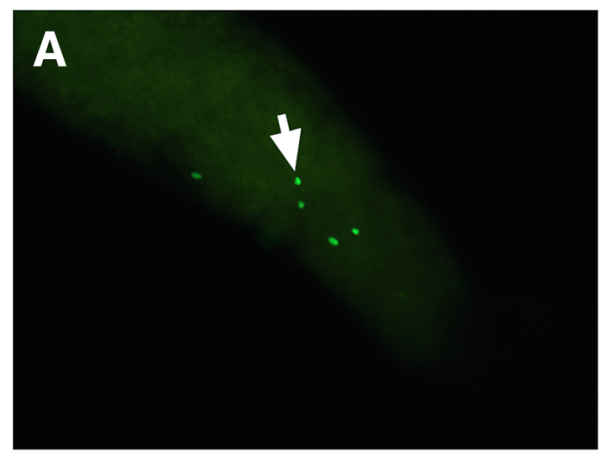

C

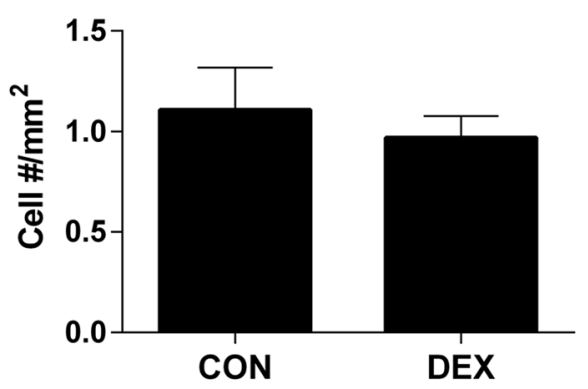

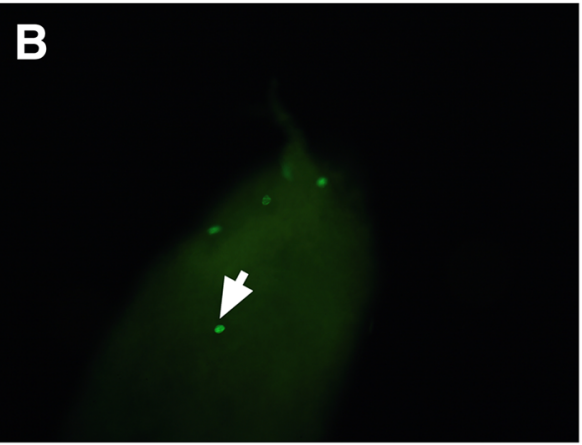

D

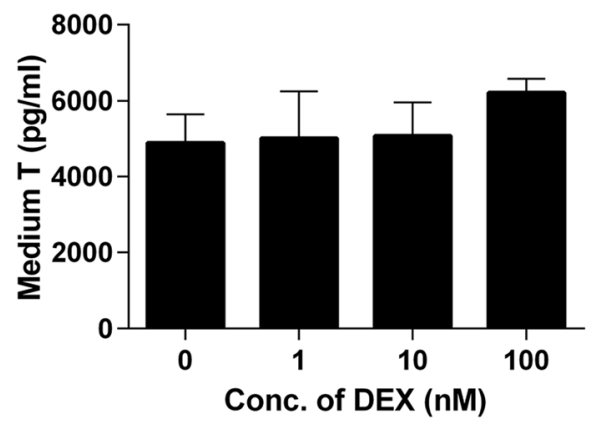

Fig. 6 DEX does not affect stem Leydig cell proliferation. Panel a-c: EDU-labeled stem Leydig cells (green color, white arrow) afte treatment in the BM for 5 days. Panel: (a) Control; (b) DEX 100 nM; (c) EDU-labeled stem Leydig cell numbers ( $n=6$ ). Panel D: Medium testosterone (T) levels after seminiferous tubules were treated with various concentrations of DEX $(0-100 \mathrm{nM})$ in the BM for 7 days and then these tubules were switched to the LIM for additional 14 days $(n=4-8)$. In Panel $\mathbf{c}$ and $\mathbf{d}$, the data were presented as the mean \pm SEM and there was no significant difference when compared to control group at $P<0.05$ 
or fibroblasts into steroidogenic Leydig cell-like cells by transcriptionally promoting the expression of steroidogenic enzymes including Cyp17a1 [34, 35]. Apparently, the exposure to DEX in rats during the prenatal period significantly increased the COUP-TFII expression in fetal Leydig cells thus down-regulating Cyp17a1 expression and inhibiting testosterone production [32]. Interestingly, DEX did not down-regulate other steroidogenic enzymes such as Cyp11a1, Hsd3b1, and Hsd17b3. This indicates that DEX partially blocks the differentiation of stem Leydig cells. How DEX can affect several steroidogenesis-related genes without affect others requires further investigation. Maybe, the DEX-mediated effects depend on the Leydig cell stages. For example, DEX inhibited steroidogenesis of progenitor Leydig cells by suppressing of Star and $H s d 3 b 1$ via a glucocorticoidmediated mechanism [16]. Besides, glucocorticoid-induced inhibition of testosterone biosynthesis occurred through the suppression of Cyp11a1, Hsd3b1, and Cyp17a1 gene expression in adult Leydig cells. [7, 36-38]. However, the inhibition on steroidogenic enzyme gene expressions was happened during a short-term culture [7, 36-38]. For example, a 6-h immobilization stress significantly increased serum glucocorticoid level but down-regulated Lhcgr, Star, Scarb1, Cyp11a1, Cyp17a1, and Hsd17b3 and reduced serum testosterone level [25]. However, in the present study, we treated the stem Leydig cells during a 21-day period and the effect of DEX was chronic.

Therefore, our study explored the mechanism of DEX to regulate rat Leydig cell development in vitro.

\section{Conclusions}

DEX inhibits the differentiation of stem Leydig cells into Leydig cell lineage via NR3C1. This suppression partially targets on Cyp17a1 and Scarb1 gene expressions.

\section{Abbreviations \\ BM: Basal medium; CYP11A1: Cytochrome P450 cholesterol side-chain cleav- age enzyme; CYP17A1: Cytochrome 17a-hydroxylase/20-lyase; DEX: Dexamethasone; EDS: Ethane dimethane sulfonate; HSD17B3: 17 $\beta$ - hydroxysteroid dehydrogenase 3; HSD3B1: 3 $\beta$-hydroxysteroid dehydrogenase 1; ITS: Insulin-Transferrin-Selenite; LH: Luteinizing hormone; LHCGR: LH receptor; LI: Lithium; LIM: Leydig cell differentiation-inducing medium; PDGFRA: Platelet-derived growth factor receptor a; qPCR: Real-time quantitative polymerase chain reaction; SCARB1: High-density lipoprotein receptor; SRD5A1: Steroid 5a-reductase 1; StAR: Steroidogenic acute regulatory protein; a-SMA: a-smooth muscle actin}

\section{Acknowledgements}

Authors thank Center of Scientific Research, the Second Affiliated Hospital and Yuying Children's Hospital of Wenzhou Medical University, Wenzhou, Zhejiang, China for providing necessary facilities for conducting the research. And Authors also thank Ren-Shan Ge's researches (Front Endocrinol (Lausanne). 2018 Jan 24;9:4. doi: https://doi.org/10.3389/fendo.2018.00004. and Mol Cell Endocrinol. 2017 Mar 15;444:1-8. doi: https://doi.org/10.1016/j.mce.2017.01.023.) for providing the part of methodology.

\section{Funding}

This study was conducted as part of General Programs (No.81370699 and 81671446) of National Natural Science Foundation of China (NSFC), funded by NSFC Council (China). The funder of the study had no role in the collection, analysis and interpretation of data, nor in the writing of the report, nor in the decision to submit the article for publication.

\section{Availability of data and materials}

The datasets analyzed during the current study are available from the corresponding author on reasonable request.

\section{Authors' contributions}

JW, GH, BS, HT, YJ and XC performed experiments; JW and DZ analyzed data; R-S and YF designed experiments and wrote the manuscript, all authors have read and approved the manuscript.

\section{Ethics approval and consent to participate}

All animal procedures were approved by the Institutional Animal Care and Use Committee of Tongji University and were performed in accordance with the the National Research Council (US) Committee Guide for the Care and Use of Laboratory Animals.

\section{Consent for publication}

The manuscript does not contain any individual person's data in any form. So, this information is not relevant.

\section{Competing interests}

The authors declare Ren-Shan Ge as an associate editor of this journal.

\section{Publisher's Note}

Springer Nature remains neutral with regard to jurisdictional claims in published maps and institutional affiliations.

\section{Author details}

'Department of Urology, Shanghai Tenth People's Hospital, Tongji University, Shanghai, China. ${ }^{2}$ Department of Urology, Yijishan Hospital, Wannan Medical College, Wuhu, Anhui, China. ${ }^{3}$ Center of Scientific Research, the Second Affiliated Hospital and Yuying Children's Hospital of Wenzhou Medical University, Wenzhou, Zhejiang, China. ${ }^{4}$ Department of Urology, Shanghai Tenth People's Hospital, Nanjing Medical University, Nanjing, Jiangsu, China.

Received: 13 October 2018 Accepted: 9 May 2019

Published online: 27 May 2019

\section{References}

1. Witorsch RJ. Effects of elevated glucocorticoids on reproduction and development: relevance to endocrine disruptor screening. Crit Rev Toxicol. 2016:46:420-36.

2. Nicolaides NC, Galata Z, Kino T, Chrousos GP, Charmandari E. The human glucocorticoid receptor: molecular basis of biologic function. Steroids. 2010; 75:1-12.

3. Meir Drexler S, Wolf OT. The role of glucocorticoids in emotional memory reconsolidation. Neurobiol Learn Mem. 2017;142(Pt A);126-34.

4. Ye L, Li X, Li L, Chen H, Ge RS. Insights into the development of the adult Leydig cell lineage from stem Leydig cells. Front Physiol. 2017;8:430.

5. Ge RS, Hardy DO, Catterall JF, Hardy MP. Developmental changes in glucocorticoid receptor and $11 \beta$ - hydroxysteroid dehydrogenase oxidative and reductive activities in rat Leydig cells. Endocrinology. 1997;138:5089-95.

6. Schultz R, Isola J, Parvinen M, Honkaniemi J, Wikström AC, Gustafsson JÅ, Pelto-Huikko M. Localization of the glucocorticoid receptor in testis and accessory sexual organs of male rat. Mol Cell Endocrinol. 1993;95:115-20.

7. Hales DB, Payne AH. Glucocorticoid-mediated repression of P450(SCC) mRNA and de novo synthesis in cultured Leydig cells. Endocrinology. 1989; 124:2099-104.

8. Rygg M, Pistorio A, Ravelli A, Maghnie M, Di lorgi N, Bader-Meunier B, Da Silva C, Roldan-Molina R, Barash J, Dracou C, et al. A longitudinal PRINTO study on growth and puberty in juvenile systemic lupus erythematosus. Ann Rheum Dis. 2012;71:511-7.

9. Odeh HM, Kleinguetl C, Ge R, Zirkin BR, Chen H. Regulation of the proliferation and differentiation of leydig stem cells in the adult testis. Biol Reprod. 2014;90:123. 
10. Stanley E, Lin CY, Jin S, Liu J, Sottas CM, Ge R, Zirkin BR, Chen H. Identification, proliferation, and differentiation of adult Leydig stem cells. Endocrinology. 2012;153:5002-10.

11. Li X, Wang Z, Jiang Z, Guo J, Zhang Y, Li C, Chung J, Folmer J, Liu J, Lian Q, et al. Regulation of seminiferous tubule-associated stem Leydig cells in adult rat testes. Proc Natl Acad Sci U S A. 2016;113:2666-71.

12. Teerds KJ, De Rooij DG, Rommerts FF, Wensing CJ. The regulation of the proliferation and differentiation of rat Leydig cell precursor cells after EDS administration or daily HCG treatment. J Androl. 1988;9:343-51.

13. Hu GX, Lian QQ, Chen BB, Prasad PV, Kumar N, Zheng ZQ. Ge RS: 7alphahydroxytestosterone affects 11 beta-hydroxysteroid dehydrogenase 1 direction in rat Leydig cells. Endocrinology. 2010;151:748-54.

14. Xiao YC, Huang YD, Hardy DO, Li XK, Ge RS. Glucocorticoid suppresses steroidogenesis in rat progenitor Leydig cells. J Androl. 2010;31:365-71.

15. Zhang L, Wang H, Yang Y, Liu H, Zhang Q, Xiang Q, Ge R, Su Z, Huang Y. NGF induces adult stem Leydig cells to proliferate and differentiate during Leydig cell regeneration. Biochem Biophys Res Commun. 2013;436:300-5.

16. Xiao YC, Huang YD, Hardy DO, Li XK, Ge RS. 81. Glucocorticoid suppresses steroidogenesis in rat progenitor Leydig cells. J Androl. 2010;31:365-71.

17. Payne $A H$, Wong KL, Vega MM. Differential effects of single and repeated administrations of gonadotropins on luteinizing hormone receptors and testosterone synthesis in two populations of Leydig cells. J Biol Chem. 1980; 255:7118-22.

18. Ge RS, Hardy MP. Decreased cyclin A2 and increased cyclin G1 levels coincide with loss of proliferative capacity in rat Leydig cells during pubertal development. Endocrinology. 1997;138:3719-26.

19. Ge RS, Dong Q, Sottas CM, Papadopoulos V, Zirkin BR, Hardy MP. In search of rat stem Leydig cells: identification, isolation, and lineage-specific development. Proc Natl Acad Sci U S A. 2006;103:2719-24.

20. Klinefelter GR, Hall PF, Ewing LL. Effect of luteinizing hormone deprivation in situ on steroidogenesis of rat Leydig cells purified by a multistep procedure. Biol Reprod. 1987;36:769-83.

21. Payne $\mathrm{AH}$, Downing JR, Wong KL. Luteinizing hormone receptor and testosterone synthesis in two distinct populations of Leydig cells. Endocrinology. 1980;106:1424-9.

22. Guo J, Zhou H, Su Z, Chen B, Wang G, Wang CQF, Xu Y, Ge RS. Comparison of cell types in the rat Leydig cell lineage after ethane dimethanesulfonate treatment. Reproduction (Cambridge, England). 2013;145:371-80.

23. Guo J, Deng H, Li H, Zhu Q, Zhao B, Chen B, Chu Y, Ge RS. Effects of methoxychlor and its metabolite 2,2-bis(p-hydroxyphenyl)-1,1,1trichloroethane on 11ß-hydroxysteroid dehydrogenase activities in vitro. Toxicol Lett. 2013;218:18-23.

24. Lin H, Ge RS, Chen GR, Hu GX, Dong L, Lian QQ, Hardy DO, Sottas CM, L XK, Hardy MP. Involvement of testicular growth factors in fetal Leydig cell aggregation after exposure to phthalate in utero. Proc Natl Acad Sci U S A. 2008;105:7218-22.

25. Lin H, Yuan KM, Zhou HY, Bu T, Su H, Liu S, Zhu Q, Wang Y, Hu Y, Shan Y, et al. Time-course changes of steroidogenic gene expression and steroidogenesis of rat Leydig cells after acute immobilization stress. Int J Mol Sci. 2014;15:21028-44.

26. Liu S, Chen X, Wang Y, Li L, Wang G, Li X, Chen H, Guo J, Lin H, Lian QQ, Ge $\mathrm{RS}$. A role of KIT receptor signaling for proliferation and differentiation of rat stem Leydig cells in vitro. Mol Cell Endocrinol. 2017:444:1-8.

27. Maric D, Kostic T, Kovacevic R. Effects of acute and chronic immobilization stress on rat Leydig cell steroidogenesis. J Steroid Biochem Mol Biol. 1996; 58:351-5.

28. Saez JM, Morera AM, Haour F, Evain D. Effects of in vivo administration of dexamethasone, corticotropin and human chorionic gonadotropin on steroidogenesis and protein and DNA synthesis of testicular interstitial cells in prepuberal rats. Endocrinology. 1977;101:1256-63.

29. Ge RS, Hardy DO, Catterall JF, Hardy MP. Developmental changes in glucocorticoid receptor and 11 beta-hydroxysteroid dehydrogenase oxidative and reductive activities in rat Leydig cells. Endocrinology. 1997; 138:5089-95.

30. Ge RS, Hardy MP. Variation in the end products of androgen biosynthesis and metabolism during postnatal differentiation of rat Leydig cells. Endocrinology. 1998;139:3787-95

31. Shibata H, Ikeda Y, Morohashi K, Mukai T, Kurihara I, Ando T, Suzuki T, Kobayashi S, Hayashi K, Hayashi M, et al. Orphan receptors COUP-TF and DAX-1 as targets in disordered CYP17 expression in adrenocortical tumors. Endocr Res. 2000;26:1039-44.
32. van den Driesche S, Walker M, McKinnell C, Scott HM, Eddie SL, Mitchell RT, Seckl JR, Drake AJ, Smith LB, Anderson RA, Sharpe RM. Proposed role for COUP-TFIl in regulating fetal Leydig cell steroidogenesis, perturbation of which leads to masculinization disorders in rodents. PLoS One. 2012;7:e37064.

33. Sadovsky Y, Crawford PA, Woodson KG, Polish JA, Clements MA, Tourtellotte LM, Simburger K, Milbrandt J. Mice deficient in the orphan receptor steroidogenic factor 1 lack adrenal glands and gonads but express P450 side-chain-cleavage enzyme in the placenta and have normal embryonic serum levels of corticosteroids. Proc Natl Acad Sci U S A. 1995;92:10939-43.

34. Yang Y, Li Z, Wu X, Chen H, Xu W, Xiang Q, Zhang Q, Chen J, Ge RS, Su Z, Huang $Y$. Direct reprogramming of mouse fibroblasts toward Leydig-like cells by defined factors. Stem Cell Reports. 2017;8:39-53.

35. Yang Y, Su Z, Xu W, Luo J, Liang R, Xiang Q, Zhang Q, Ge RS, Huang Y. Directed mouse embryonic stem cells into leydig-like cells rescue testosterone-deficient male rats in vivo. Stem Cells Dev. 2015;24:459-70.

36. Srivastava RK, Taylor MF, Mann DR. Effect of immobilization stress on plasma luteinizing hormone, testosterone, and corticosterone concentrations and on $3 \beta$-Hydroxysteroid dehydrogenase activity in the testes of adult rats. Proc Soc Exp Biol Med. 1993;204:231-5.

37. Payne $A H$, Sha L. Multiple mechanisms for regulation of $3 \beta$-hydroxysteroid dehydrogenase/ $\Delta 5 \rightarrow \Delta 4$-isomerase, 17a-hydroxylase/C17-20 lyase cytochrome P450, and cholesterol side-chain cleavage cytochrome P450 messenger ribonucleic acid levels in primary cultures of mouse leydig cells. Endocrinology. 1991;129:1429-35.

38. Welsh TH Jr, Bambino TH, Hsueh AJW. Mechanism of glucocorticoidinduced suppression of testicular androgen biosynthesis in vitro. Biol Reprod. 1982;27:1138-46.

\section{Ready to submit your research? Choose BMC and benefit from:}

- fast, convenient online submission

- thorough peer review by experienced researchers in your field

- rapid publication on acceptance

- support for research data, including large and complex data types

- gold Open Access which fosters wider collaboration and increased citations

- maximum visibility for your research: over $100 \mathrm{M}$ website views per year

At BMC, research is always in progress.

Learn more biomedcentral.com/submissions 